\section{FIRST REPORT OF REEVE'S GROUND SKINK SCINCELLA REEVESI AND HIMALAYAN LITTER SKINK SPHENOMORPHUS INDICUS FROM BANGLADESH}

\section{Monirul H. Khan}

Department of Zoology, Jahangirnagar University, Savar, Dhaka 1342, Bangladesh

Email:mmhkhan@hotmail.com

plus web supplement of 1 page

Two species of skinks have been recorded for the first time in Bangladesh. These are Reeve's Ground Skink Scincella reevesi (Gray, 1839) and Himalayan Litter Skink Sphenomorphus indicus (Gray, 1853). Earlier reports (Khan, 1982, 2004; Sarker \& Sarker 1988; IUCN Bangladesh 2000) did not record the occurrence of the above-mentioned species in Bangladesh. All the species mentioned in this note were found during a survey in the mixed evergreen forests in northeastern and southeastern Bangladesh, conducted from March to June 2006. The areas are Rema-Kalenga Wildlife Sanctuary, Lawachara National Park and Satchori National Park in the northeast $\left(24^{\circ} \mathrm{O} 5^{\prime}-\right.$ $24^{\circ} 40^{\prime} \mathrm{N} \& 91^{\circ} 25^{\prime}-92^{\circ} 15^{\prime} \mathrm{E}$, altitude: $\left.30-60 \mathrm{~m}\right)$ and Teknaf Game Reserve, Chunati Wildlife Sanctuary, Sangu Reserve Forest, Matamuhuri Reserve Forest and Kassalong Reserve Forest in the southeast $\left(20^{\circ} 50^{\prime}-23^{\circ} 45^{\prime} \mathrm{N} \& 91^{\circ} 50^{\prime}-92^{\circ} 45^{\prime} \mathrm{E}\right.$, altitude: $50-$ $300 \mathrm{~m})$.

The Reeve's Ground Skink (Image $1^{\mathrm{w}}$ ) was observed and photographed in Lawachara and Teknaf, but the species might also occur in the neighbouring forested areas. It appears to be less common, but not rare. The Reeve's Ground Skink was seen on wet areas on slopes, with some lower plants. The characteristics and photograph of the species were fully matched with the characteristics mentioned by Smith (1935), and the characteristics and photograph published in Das (2002). This small ( $c a .5 \mathrm{~cm}$ from snout to vent) and slender skink had relatively short snout and limbs; brownish dorsum with small black spots, a black stripe along the sides (starting from the eyes), and creamy belly. Since the species was recorded from the neighbouring Myanmar and from Nepal, its occurrence in northeastern India (Das, 2002) and Bangladesh is not surprising. The global distribution of the species is from Nepal eastwards through Myanmar, southern China, Thailand, Vietnam, Cambodia, Laos and Korea (Welch et al. 1990; Das, 2002).

The Himalayan Litter Skink (Image $2^{\mathrm{w}}$ ) was observed and photographed in Satchori on 25 June 2006, but it might also occur in other forested areas in the northeast. It is probably rare in its habitats in Bangladesh. It was seen twice, on moist litters. It appeared more secretive than other skinks found in that area. The characteristics and photograph fully matched with the characteristics and photograph published in Das (2002). This medium-sized ( $c a$. $8 \mathrm{~cm}$ from snout to vent) slender skink was characterized by having the head distinct from neck, short snout and deeply sunk tympanum; had dark blackishbrown dorsum (which was virtually unpatterned), dark-barred lips and creamy belly. Since the species is commonly found in
India (Sikkim, northern West Bengal and Meghalaya states), Myanmar and Bhutan, it was very much expected in Bangladesh. The species is distributed eastwards up to southern China, Tibet, Taiwan, Indo-China, Thailand and the Malay Peninsula (Welch et al., 1990; Das, 2002).

The Spotted Litter Skink Sphenomorphus maculatus (Blyth, 1853) (Image $3^{w}$ ) was observed and photographed in all the areas surveyed. It was seen on fallen leaves and logs and on bare ground. The characteristics and photograph of the species undoubtedly matched with the characteristics and photograph published in Das (2002). It is a small ( $c a .6 \mathrm{~cm}$ from snout to vent) and slender skink with head distinct from neck. Golden brown dorsum commonly with two dark median series of spots and a white spotted dark lateral band on the sides of the body. The only previous record of the species is from Teknaf (Khan, 2004), but the sightings of the species during my survey indicates that the species has a wide distribution along the hilly areas of the eastern parts of Bangladesh.

The Flying Lizard Draco maculatus (Gray, 1845) (Image 4 ${ }^{\mathrm{w}}$ ) was seen and photographed on 15 April 2005 in Teknaf and on 26 March 2006 in Rema-Kalenga. The species was identified on the basis of the descriptions by Boulenger (1890) and Smith (1935). Two of them close to each other (probably pairs) were sighted in both cases, both were brownish-grey but one darker than than the other in both cases. These mediumsized lizards ( $c a .8 \mathrm{~cm}$ from snout to vent) had pointed end of the gular pouch. The pale yellowish gular pouch had a distinct blue spot at the base, and pinkish wing-membranes had black spots. The first sighting was on a planted Swietenia mahagoni and the second sighting was on a Dillenia pentagyna tree, both were on the tree bark $4-8 \mathrm{~m}$ above the ground. The only previous sight record of Draco sp. in Bangladesh was in May 1978 from the mixed evergreen forest of Hazarikhil Wildlife Sanctuary in the southeast (Khan, 1982).

\section{REFERENCES}

Boulenger, G.A. (1890). The Fauna of British India, including Ceylon and Burma: Reptilia and Batrachia, London, 8vo. 541pp.

Daniel, J.C. (2002). The Book of Indian Reptiles and Amphibians. Bombay Natural History Society, Mumbai, and Oxford University Press, Mumbai, $238 \mathrm{pp}$.

Das, I. (2002). A Photographic Guide to Snakes and Other Reptiles of India. New Holland, London, 144pp.

IUCN Bangladesh (2000). Red Book of Threatened Amphibians and Reptiles of Bangladesh. IUCN - The World Conservation Union, Dhaka, 95pp.

Khan, M.A.R. (1982). Wildlife of Bangladesh: A Checklist. University of Dhaka, Dhaka, 173pp.

Khan, M.A.R. (2004). Checklist of the herpetofauna of Bangladesh. Cobra 57: 1-29.

Sarker, S.U. \& N.J. Sarker (1988). Wildlife of Bangladesh (A Systematic List With Status, Distribution and Habitat). The Rico Printers, Dhaka, 59pp. Smith, M.A. (1935). The Fauna of British India, Including Ceylon and Burma (Vol. II: Sauria). Today \& Tomorrow's Printers \& Publishers, New Delhi (1995 edition), 440pp.

Welch, K.R.G., P.S. Cooke \& A.S. Wright (1990). Lizards of the Orient: $A$ Checklist. Robert E. Krieger Publ. Co., Florida, 162pp.

${ }^{w}$ See Images in the web supplement at www.zoosprint.org

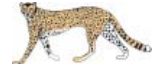

Manuscript 1581; (c) ZOO; Date of publication 21 December 2006 Received 21 June 2006; Revised received 09 November 2006; Finally accepted 10 December 2006 